\title{
REVISITING THE EXISTENCY OF IB'S NICHE PRODUCT: A Case of Mudharabah Contract in Selected BMT in Yogyakarta
}

\author{
Yuli Utami1a Abdil Fadhil Ridho ${ }^{2 b}$ \\ International Program for Islamic Economics and Finance \\ Economics Faculty of Universitas Muhammadiyah Yogyakarta \\ E-mail : 1ayuliutami@umy.ac.id, 2babdilfadhilridho@umy.ac.id
}

(Diterima oleh Dewan Redaksi: 20-01-2016)

(Dipublikasikan oleh Dewan Redaksi:01-06-2016)

\begin{abstract}
Dalam sistem keuangan Islam, Mudharabah dikenal sebagai niche product-nya lembaga keuangan Islam (produk transaksi yang sangat pantas bagi lembaga keuangan Islam karena adil, menjunjung empati terhadap mudharib, dan mendukung pertumbuhan ekonomi). Namun, fakta mengatakan bahwa Mudharabah bukanlah pembiayaan favorit. Tulisan ini bertujuan untuk melihat apakah pembiayaan Mudharabah masih layak dijadikan nicheproduct dengan mengidentifikasi peningkatan pendapatan, konsumsi, dan investasi dari para anggota setelah menjadi mitra BMT. Metode dalam makalah ini menggunakan metode deskriptif kuantitatif. Melalui rumus Slovin dan regresi linier berganda, penelitian ini akan mengevaluasi pendapatan 95 responden (Y), konsumsi(C), dan Investasi mereka (I), serta menganalisis pengetahuan mereka tentang produk yang ditawarkan (Pr), empati lembaga keuangan mikro syariah ke anggota (G), dan nisbah bagi hasil yang mereka setujui (Ps). Temuan dalam penelitian ini menunjukkan bahwa konsumsi anggota BMT dan Investasi mereka memiliki hubungan positif dengan pendapatan mereka dalam jangka panjang; dan produk yang ditawarkan, empati dari BMT ke anggota, serta nisbah bagi hasil yang mereka setujui juga terrespon positif terhadap meningkatnya pendapatan mereka. Ini berarti bahwa konsep niche-product-nyalembaga keuangan Islam masih bisa diandalkandan diterapkan di tingkat lembaga keuangan mikro.
\end{abstract}

\section{Keywords: Niche Product, Mudharabah, Profit Sharing, Emphaty}

Yuli Utami. 2015. Revisiting The Existency Of Ib's Niche Product: A Case Of Mudharabah Contract In Selected Bmt In Yogyakarta : (5) 208 -220

\section{Research Background}

The basic principle of PLS is that, instead of lending money at a fixed rate of return, the banker forms a partnership with the borrower thereby sharing in a venture's profits and losses. Mudharabah as a financing instrument is the earliest to be proposed in literature on Islamic banking (Siddiqi, n.d.) and the principal alternative for replacing interest-bearing transactions
(Choudhury, n.d.). It is important instrument for making the elimination of riba effectively (Choudhury, n.d.).

Mudharabah also promotes distributive justice by alleviating concentration of wealth or income disparities via equitable reallocation of productive resources and mobilization of resources rather than surplus of funds (Al-Harran, n.d.). If it translated to the Islamic Bank (IB) words, bank's objective should be 
maximization of social benefit not profit maximization.

Baitul Mal wat Tamwil (BMT) as an institution that designed for ground level economy and work for the maximization of cooperation or social benefit, presently, looking a resemble of an IB. More and more, the supervision will takeover by the Financial Service Autority (OJK) for next coming year 2015, therefore, the existance of this nieche product needs to evaluate immediately.

Currently, the Central Bank report shows the unconsiderable anxiety rank for the Mudharabah contract which is not even twelve percent compared to the other contracts:

Table.1 Financing Composition of Islamic Commercial Bank and Islamic Business Unit

\begin{tabular}{|c|c|c|c|c|c|l|}
\hline \multicolumn{7}{|c|}{$\mathbf{2 0 1 6}$} \\
\hline Jan & Feb & Mar & Apr & Mei & Jun & \\
\hline 20.195 & 20.683 & 21.259 & 21.564 & 22.384 & 23.898 & 1. Profit Sharing Financing \\
6.663 & 6.654 & 6.722 & 6.678 & 6.753 & 6.876 & a. Mudharabahh \\
13.533 & 14.028 & 14.537 & 14.886 & 15.631 & 17.022 & b. Musyarakah \\
- & - & - & - & - & - & c. Other Profit Sharing Financing \\
30.004 & 30.523 & 30.847 & 31.299 & 31.731 & 32.241 & 2. Receivables/Acceptables \\
28.727 & 29.227 & 29.538 & 29.964 & 30.358 & 30.838 & a. Murabahah \\
626 & 637 & 642 & 667 & 704 & 717 & b. Qardh \\
652 & 660 & 667 & 667 & 669 & 686 & c. Istishna' \\
8.821 & 8.613 & 8.409 & 8.026 & 8.022 & 7.892 & 3. Ijarah including Leasing receivables \\
- & - & - & - & - & - & a. Sindication Financing \\
22 & 22 & 7 & 7 & 7 & 7 & b. Financing through Channeling \\
- & - & - & - & - & - & c. Financing through Executing \\
8.799 & 8.591 & 8.402 & 8.019 & 8.015 & 7.885 & d. Other Ijarah \\
- & - & - & - & - & - & 4. Salam \\
\hline $\mathbf{5 9 . 0 2 1}$ & $\mathbf{5 9 . 8 1 9}$ & $\mathbf{6 0 . 5 1 5}$ & $\mathbf{6 0 . 5 1 5}$ & $\mathbf{6 2 . 1 3 6}$ & $\mathbf{6 4 . 0 3 1}$ & \\
\hline
\end{tabular}

*) Provisional figures, reported in statistics of www.ojk.go.id

The Mudharabah paradox also circled among micro enterprise institutions such BMT, where, it were not even become unfavourite financing contract due to costly and risky, but also it use to accumulate the depositors saving accounts.

Indeed, IB and BMT receives funds from people and enterpreneur and channels it to other people and entrepreneurs who need them. However, some findings showed the fact, that several BMT offer the Mudharabah account and deposits, yet, finance it in the other type of contracts. (Utami, 2014).

Therefore, this research will discuss how far Mudharabah contribute to the welfare (the increment of their income, consumption and investment) through BMT especially in Yogyakarta city which is represented by the increasing of member knowledge to the Mudharabah, profit sharing rate determination and BMT staff's emphaty to the member.

\section{RESEARCH QUESTION, LOCATION AND PURPOSES}

The research problems are stated as follows "does Mudharabah contribute to the welfare of Yogyakarta's citizen?" This research will held in five areas of Kota 
Yogyakarta, and it aims to achieve the following objectives:

a. To identify the influences of Mudharabah, empathy and profit sharing ratio determination toward MSEs' funding

b. To analyse whether the improvement of welfare, i.e. income, consumption, and investment of the members are influenced by the contribution of Mudharabah Contract.

\section{Literature Review}

Satisfaction level and welfare is two definitions which are related each other. Satisfaction level refers to individual or party condition, whether welfare refers to community or society conditions. Welfare is an aggregate condition from individual satisfaction.

Enactment of Republic of Indonesia No. 112009 about social welfare, says that the Social Welfare is the fulfillment of the condition of the material, spiritual, and social life of citizens in order to be viable and able to develop them, so that it can carry out its social function.

Public welfare of middle and lower class can be represented from their living standard; it can be marked with the alleviation of poverty, the acquisition of a higher education level, and the level of productivity of the community (Todaro, 2003:46).

Indonesian Central Bureau of Statistics (2000) explains that in order to see the level of household wealth of an area there are several indicators that can be used as a measurement, they are:

1. The level of family income;

2. The composition of household expenditure by comparing expenditures on food and nonfood;
3. The level of family education;

4. The level of family health, and;

5. Housing conditions and facilities owned by the household.

Therefore, a person can be said to have been prosperous if he gained increased revenue, since it will influencing the increasing of consumption either for production or non-production, or an increasing in the investments. The variable among income, consumption and investment are related each other.

In micro scale, income is a sum of investment and consumption. If the income decreases while the consumption is constant, the investment or saving will decrease from before. If the income decreases while the consumption decreases too, the investment or saving will decrease proportionately. In the other hand, if the income increases while the consumption is constant, the saving will increase; or if the income increases while the investment is constant, the consumption will increase. (Mankiew,2007:2)

Income is the monetary payment received in exchange for providing a good or service, or from other sources, as rents or investments. In micro scale, generally the circulation flow of income shows the flows of production, income, goods, services, and the expenditure factor between firm and household sectors.

Mankiew explained in his books that households' consumption decisions affect the way the economy as a whole behaves both in the long run and in the short run. The consumption decision is crucial for long run analysis because of its role in the economic growth. As well as consumption decision is crucial too for 
short run analysis because of its role in determining aggregate demand. Consumption is two-third of GDP, so fluctuations in consumption are a key element of booms and recessions. (Mankiew, 2007:456)

In 1936, Keynes made the consumption function central to his theory of economic fluctuations, and it has played a key role in macroeconomic analysis ever since. Instead of relying on statistical analysis, Keynes made conjectures about the consumption function based on introspection and casual observation(Mankiew, 2007:457). They are :

- The marginal propensity to consume (MPC) is between zero and one

- The ratio of consumption to income, called the average propensity to consume, falls as income rises.

- Income is the primary determinant of consumption and that the interest rate does not have an important role.

According to Mankiew,
households with higher income
consumed more, which confirms that
the marginal propensity to consume is
greater than zero, while household
with higher income saved more, which
confirms that the marginal propensity
to consume is less than zero. In
addition, the higher-income
households saved a large fraction of
their income, which confirms that the
average propensity to consume falls as
income rises (Mankiew, 2007:459)
In the futures when income was
unusually low, such as during the
depths of the Great Depression, both
consumption and saving were low,
indicating that the marginal

propensity to consume is between zero and one. In addition, during those years of low income, the ratio of consumption to income was high, confirming Keynes's second conjecture.

Finally, because the correlation between income and consumption was so strong, no other variable appeared to be important for explaining consumption. Thus, the explanation above also confirmed Keynes's third conjecture that income is primary determinant of how much people choose to consume (Mankiew, 2007:487)

Investment plays a key role not only in long run growth but also in the short run business cycle because it is most volatile component of GDP. When expenditure on goods and services falls during a recession, much of the decline is usually due to a drop in investment.

During U.S. recession at 1982 for example, real GDP of U.S. fell $\$ 105$ billion from its peak in the third quarter of 1981 to its trough in the fourth quarter of 1982. Investment spending over the same period fell $\$ 152$ billion, accounting for more than the entire falls in spending (Mankiew, 2007:487)

Driven by a sense of deep concern to many poor people who are caught by moneylenders, Indonesian government support the Bayt al-Maal Wa al-Tamwil (BMT) as a micro financial institution which enhances the economic empowerment programs, especially among micro, small, medium and cooperative through the Islamic system.The term of Baitul Maal means house of money and Baitul Tamwiil means financing house(Andriani,2005:249). This term already existed since Rasulullah era 
even though it didn't established formally as an institution and separated each other. But, in Caliph Umar bin Khattab era, Baitul Maal established as a formal economic institutions suggested by jurist named Walid bin Hisyam. Since this period and triumph of Islam while Dynasty Abbasid and Umayyad) Bayt al-Maal has become an institution that had important role for the country life.

At that time, the Bayt al-Maal has handling various matters either from withdrawal zakat, ghanimah, infaq, shadaqah or to build public facilities such as roads, bridges, hiring soldiers and officials countries, and other public interests. Meaning to say that the Bayt al-Maal in Caliph Umar bin Khattab period until the triumph of Islam period can be said as the Ministry of Finance, Directorate General of Taxation, Ministry of Social Affairs, Ministry of Public Works and so on at once(Andriani,2005:250).

The concept of BMT in Indonesia has been rolling over a decade. This concept has proved in overcoming and reducing poverty. BMT has strategic role to reduce poverty seeing the fact that the banking institutions have not been able to touch the grassroots. The strategic role of BMT in reducing poverty can be seen by its economic activities that have a social activity (Bayt al-Maal) and business activities (Bayt al-Tamwil). Socio-economic activities carried out like zakat, sadaqah and infaq while business activity by financing productive economy. (Andriani,2005:250).

According to the Minister of Cooperatives and SMEs Act number 91, 2004 about Activity Guidelines KJKS Chapter I Article 1 said, that "the implementation guidance of BMT as Shari'ah microfinance institutions and incorporated Islamic financial cooperatives should comply with the Shari'ah financial services, namely business activities engaged in financing, investment, and savings based on profit and loss sharing." Asian Development Bank (ADB) noted about micro finance institution that the institutions should provide deposits, loans, payment services and insurance to poor and low income households and their microenterprises(Andriani,2005:250). Bayt al-Tamwil has three principles in its practices. First, loss and profit sharing system which use two types contracts, i.e. Mudharabahh (trustee partnership) and Musyarakah (joint venture) contract. The former involves a combination of entrepreneurship and capital while the latter involves a partnership in entrepreneurship and capital. These equity-based products are unique to Islamic banking and in some sense, account for its superiority over conventional banking on grounds of ethics and efficiency. Therefore, these two financing products are the niche product for Islamic financial institution because of its disparity with conventional one (Obaidullah,2005:57).

Second, sell and purchase system which use two general selling price, i.e exchange goods for money (Murabahah, Bay' Bithaman 'Ajil, Istisna' and Salam) and exchange services for money (Ijarah, Wakalah, Kafalah); Third, non profit contract (Qard Hasan).This research will focus on the niche products in BMT that contracts only use in Islamic Financial institutions.

In Mudharabah, profit is shared according to a pre-agreed ratio. If mudarib losses, losses entirely 
absorbed by the capital provider (Islamic Financial institution). Mudharabah may be of two types restricted or unrestricted. In a restricted mudharabah (mudharabah al-muqayyada) the bank or the financier may specify a particular business in which investments may be undertaken. Mudharabah may also be an unrestricted one (Mudharabah almutlaqa); in which case the mudaribmay invest the capital provided in any business he deems fit. (Obaidullah,2005:57-58)

The robbulmal or shareholders own the business's net worth, while the mudharib or the managers control the business's assets. The moral hazard problem arises when the mudarib is motivated to maximize the business's value as the owners do. Hence, to determine the proper utilization of the Mudharabah fund by the mudarib, a detailed and costly monitoring system is an important factor to consider (Rosly,2207:193) A joint venture musharakah shares the profit between the financier and the customer in the pre-agreed ratio. tolerated are $1 \%, 5 \%$, and $10 \%$. (Sunyoto,2013:16). Hence, for this research, the researcher takes $10 \%$ of error that can be tolerated. Thus, the respondents that participate in this research are around 95 participants.

\section{Sampling}

This research was conducted in BMTs under PUSKOPSYAH supervisor in Yogyakarta city. The research takes 95 respondents randomly in 5 BMTs that placed in 5 areas in Jogja city, they are BMT Beringharjo (Central city), BMT Bina Ihsanul Fikri (West Jogja city), BMT Bina Sparta Mandiri (North Jogja city), BMT Al-Ikhlas (South Jogja
Losses are shared strictly in proportion to their respective capital contributions. (Obaidullah,2005:59)

\section{Research Methodology and Findings Discussion}

\section{RESEARCH SUBJECT}

The determination of sample estimation in this research uses Slovin formula:

$$
\begin{aligned}
& \text { Where: } \mathrm{n} \text { : the } \\
& \text { amount of sample } \\
& \mathrm{N} \text { : the amount } \\
& n=\frac{N \quad \text { of population }}{1+N e^{2}} \quad \text { e: percentage } \\
& \text { of error that can be } \\
& \text { tolerated based on } \\
& \text { statistic }(1 \%, 5 \%, \\
& 10 \%)
\end{aligned}
$$

Based on data in http://umkm.jogjakota.go.id/, it is said that UMKM in Yogyakarta city is about 2082 data; and according Slovin formula, the percentages of error that can be

City), and BMT BAROKAH Padi Melati (East Jogja city).

\section{Variables and Data Collecting Method}

In this research, dependent variable that used by researcher is BMT members' welfare (Y). Meanwhile, independent variables that used are the value of Islamic financial institution product offered toward their member $\left(\mathrm{X}_{1}\right)$, the empathy of Islamic financial institution toward its member $\left(\mathrm{X}_{2}\right)$, and profit sharing ratio in their Islamic financial institution $\left(\mathrm{X}_{3}\right)$.

Data that used in this research is primary data by using sample and 
sampling method. Sampling method selected to this research is simple random sampling method. Whereas data collection method that used in this research is by questionnaire for several BMT members.

\section{VALIDITY TEST:}

A TRIAL OF A DATA CAN BE SAID AS VALID IF $\mathrm{R}$ GREATER R-TABLE BY USING FORMULA AS BELOW:

$$
\Gamma x y=\frac{\mathrm{N} \sum x y \pm(\Sigma x)(\Sigma y) \quad \text { From } 64,2 \% \text { female and } 35,8 \% \text { male }}{\sqrt{\left(\mathrm{N} \Sigma x^{2}-(\Sigma x)^{2}\right\}\left(\mathrm{N} \Sigma y^{2}-(\Sigma y)^{2}\right.} \text { respondents, this test found: }}
$$

\begin{tabular}{|c|c|}
\hline $\begin{array}{c}\text { Validity } \\
\text { Test }\end{array}$ & The Findings and The Elaboration \\
\hline 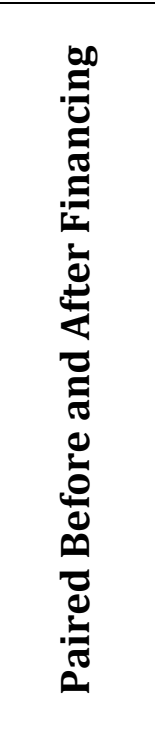 & $\begin{array}{l}\text { The income average of respondents before financing is } 1.74 \text { and after } \\
\text { financing is } 2.05 \text {. However, by using significant level } 5 \% \text {, the correlation } \\
\text { between two variables is } 0.141 \text { with its significant is } 0.17 \text {. The result shows } \\
\text { that there is no correlation between two income averages before and after } \\
\text { financing. It happens because the revenue of traders in Yogyakarta is } \\
\text { depended on seasons. At peak season, they can get higher revenue than } \\
\text { usual. In the other hand, at low season their revenue is stable. T test value } \\
\text { gives - } 6.584 \text { with significant value } 0.000 \text {, which means less than } 0.05 \text {. } \\
\text { Therefore, it can be concluded that income average before and after } \\
\text { financing is different which indicates that financing taken influences their } \\
\text { incomes. It is because the traders increase their capital formation by using } \\
\text { the BMT's financing. Based on macroeconomic theory, the increasing of } \\
\text { factor of production such as capital and labor can increase the output of } \\
\text { production and the increasing of output can increase the income of traders. } \\
\text { (Mankiew,2007:46) }\end{array}$ \\
\hline 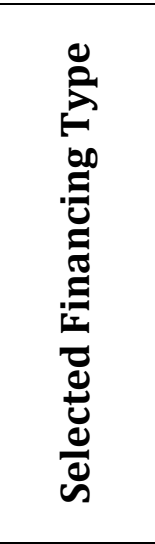 & $\begin{array}{l}\text { Musharakah, is likely to be higher demanding contract compared to } \\
\text { Mudharabah by having } 87,4 \% \text { of total. Surprisingly, Mudharabah, supposed } \\
\text { being contract for majority business of respondents those jobs are trader, } \\
\text { is only } 12.6 \% \text { of total contract used in transactions between BMT and } \\
\text { respondents. It may because Mudharabah contract has a higher market risk } \\
\text { and costly contract compared to musharakah in the short run. Though, it is } \\
\text { a niche product of Islamic Financial institution and use friendly ratio } \\
\text { portion of nisbah, yet, BMTs prefer to recommend musharakah contract to } \\
\text { their member to cover profit and loss sharing together. But in the long run, } \\
\text { Mudharabah could be a pledge contract which can contribute higher trust } \\
\text { from the member and embrace more newly enterpreneur. }\end{array}$ \\
\hline
\end{tabular}

Table 2.Validity Findings variable $x$ and variable $y$

$\sum \mathrm{x}=$ amount from item score

$\sum y=$ amount of total score

$\mathrm{N}=$ amount of subject

$\sum x y=$ sum of time of item and total score

$\sum x^{2}=$ quadrate mount of item score

$\sum y^{2}=$ quadrate mount of total score
Where:

$\Gamma x y=$ correlation coefficient between

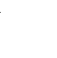


$43.2 \%$ of respondents took financing from the range of 6 million until 10 million and 38.9\% took the financing on the range 1 million untill 5 million and the rest $(17.9 \%)$ took the financing around the range 10 million until 25 million. It shows that the low level financing is one type of BMT financing.

\section{Reliability Test}

Reliability test is a tool to measure a questionair which in an indicator of variables or to construct the researches. A questionair can be considered as reliable if the answers are consistent or stable time to time (Mankiew,2007:28). Researcher uses Cronbach alpha's formula and found all the variables are reliable: BMT member's welfare 0.836; Product value 0.709; BMT's emphaty 0.753; Profit Sharing 0.651.

$\propto=\frac{k-\bar{r}}{1(k-1) \bar{r}}$

Where:

$\bar{r}=$ correlation mean among items

$\mathrm{K}=$ amount of item

\section{Descriptive Variables Analysis}

Each respondent was given 20 questions with each question was measured using a Likert scale. Questionnaires were given to respondents in the form of questions that asked respondents to give their opinions or experiences after using the products and services offered by the BMTs.The full sequence is worth five (5) for strongly agree response, score four (4) for agree, score three (3) for neutral, the score two (2) for does not agree and score one (1) for strongly disagree respectively.

The dependent variable or variable $Y$ consists of three questions, while the independent variables or variable $\mathrm{X} 1$, $\mathrm{X} 2$, and $\mathrm{X} 3$ consist of four questions. The respondents' welfare indicatedincrease from the increasing in their investments, incomes andconsumptions which are summarize from 26 respondents on average $(27.37 \%)$ who are really agree and strongly agree. The total increasing in investmentconcluded based on the positively change in capital formation (18.26\%), saving (9.21\%) and household furniture (6.16) those are significantly got highest response. The positive change on average income after financing summarized base on the change of revenue $(6.63 \%)$, product sold $(4.74 \%)$ and product ordered $(2.53 \%)$ those have highest response as well. The positive change of respondents consumption that concise from the basic needs (11.11\%), business cost (4.26\%), and operationalcost (1.58\%), also received highest response. Product offered, emphaty given by BMT, determination of profit sharing ratio, all together receive answer majority agree and strongly agree gives positive advantage to their business.

\section{DATA ANALYSIS METHOD}

1. Multiple Linear Regression: In this research, the researcher uses this regression equation:

$$
\begin{aligned}
& \mathbf{Y}=\mathbf{a}+\mathbf{b} \mathbf{X}_{1}+\mathbf{c} \mathbf{X}_{2}+\mathbf{d} \mathbf{X}_{3}+\mathbf{e} \\
& \text { Which } \mathrm{Y}=\mathrm{BMT} \text { members' welfare } \\
& \mathrm{X}_{1}=\text { value of BMTs' product offered } \\
& \text { toward their member } \\
& \mathrm{X}_{2}=\text { empathy of BMT member } \\
& \text { toward its member } \\
& \mathrm{X}_{3}=\text { Profit sharing ratio intheir BMT } \\
& \mathrm{e}=\text { error term }
\end{aligned}
$$




\section{Determination coefficient $\left(R^{2}\right)$ :}

This $\mathrm{R}^{2}$ determination is used for measuring the proportion of dependent variables which is explained by independent variables (Qudratullah,2013:71). $\mathrm{R}^{2}$ value is placed between $0 \leq \mathrm{R}^{2} \leq 1$. The closer to 1 , the better the model obtained.

$$
\mathrm{R}^{2}=1-\frac{\text { SSerr }}{\text { SStot }}
$$

3. Statistic test: This statistic test is used for measuring Goodness of fit which is consists of:

\section{a. T-test}

$\mathrm{T}$ test is done for finding out the influences of independent variables toward dependent variable individually. The used hypotheses are: $H o: \beta 1=\beta 2=\beta 3$ $=0$ (it means that there is no relationship between the value of BMTs' product, empathy of BMT toward its member, and profit sharing ratio in their BMT with welfare of BMT members). $H a: \beta 1 \neq \beta 2 \neq \beta 30$ (it means that there is relationship between the value of BMTs' product, empathy of BMT toward its member, and profit sharing ratio in their BMT with welfare of BMT members).

\section{b. F-test}

$F$ test is done for finding out the influences of independent variables toward dependent variable jointly. The conclusion of $F$ test can be found by comparing between $\mathrm{F}$ test statistic with $\mathrm{F}$ table at certain level and certain degree. This test is done by formula as below :

$$
F=\frac{R^{2} / k}{\left(1-R^{2}\right)-(n-k-1)}
$$

Which is:

$\mathrm{R}^{2}$ : determination coefficient

$\mathrm{k}$ : the amount of assumption parameter

$\mathrm{n}$ : the amount of sample

\section{Classical assumption test}

\section{a. Multicollinearity Test}

Multicollinearity test is done in order to check the correlation among independent variables. If there is a correlation, it means that there is a multicollinearity problem. The good regression model is there is no correlation among independent variables.

\section{b. Heteroskedasticity test}

Heteroskedasticity test is done in order to examine whether there occurs an inequalities of regression model residual variance from one observation to another observation. (Qudratullah,2013:192) 
Table 3. Discussion of Findings

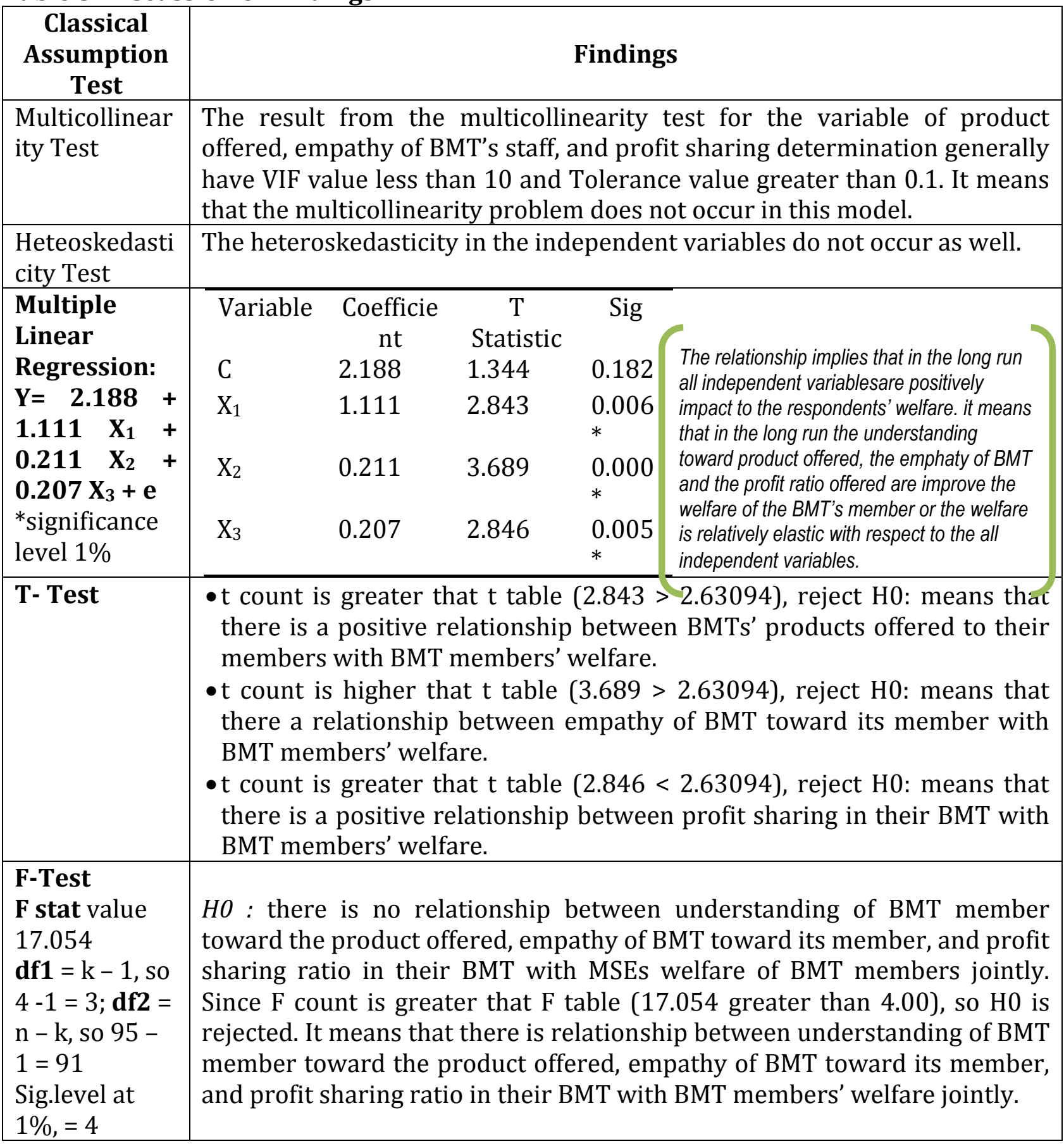




\begin{tabular}{|l|l|}
\hline $\begin{array}{l}\mathbf{R}^{2} \text { Test }= \\
0.360 \text { or } \\
(36 \%)\end{array}$ & $\begin{array}{l}\text { the percentage contribution of the effect of independent variables } \\
\text { (product, empathy, and profit sharing) on the dependent variable (BMT } \\
\text { members' welfare) is equal to 36\%; or variations of the independent } \\
\text { variables used in the model (product, empathy, and profit sharing) were } \\
\text { able to explain 36\% of variation in the dependent variable (BMT members' } \\
\text { welfare). Meanwhile, the remaining 64\% are influenced or explained by } \\
\text { other variables that are not included in this research model. It may because } \\
\text { the most use contract those used by the respondents are Musharakah, } \\
\text { since the Mudharabah were given only to the skillful enterpreneur for his } \\
\text { prospectus enterprise. Due to the lack of human resource in BMT who are } \\
\text { capable in guiding the new business, therefore Mudharabah still } \\
\text { considered as costly and riskies contract. This problems need a deep } \\
\text { research looking for the solution for the application of Mudharabah. }\end{array}$ \\
\hline
\end{tabular}

\section{Conclusion and Recommendation}

This research demonstrated that Mudharabah have positive impact on the increasing of Yogya City's citizen welfare. The improvements can be seen from the increasing of their investments, consumption, and incomes. Most of respondents stated that BMTs are helpful in supporting their business growth. From product value aspect, BMTs have simple procedure for financing product offered toward their members. Hence, BMTs' members can increase their business growth because of BMTs can help them in fulfilling working capital needed by micro enterprises. From empathy aspect, BMTs have no burden for installments payment or some penalties for whose cannot pay the installment in time like conventional financial institutions. Besides, proactive systems done by BMTs, it can help and simply traders to pay installments as well as to save their funds. From profit sharing aspect, BMT apply the fairness in deciding profit sharing ratio without burdening their members by conducting discussion and agreement during contract.
However, Mudharabah contract found as a higher market risk and costly contract compared to musharakah in the short run which proven by the small percentage of choosing this contract rather than Musharakah. Therefore, as a niche product of Islamic Financial institution, Mudharabah suggest to be offered to the member for long run financing, since it contribute higher trust from the member and embrace more newly enterpreneur.

Given that Mudharabah have contribution to increase social welfare, in the future, it is expected that government can intensify its support toward Islamic microfinance institutions, especially BMTs rather than pouring money to the people without strong rationale and base. Government can channel a proportion of public budget by empowering the skillsand micro-enterprise through BMTs, and then BMTs can manage this fund for social interests through Islamic Financial Institution niche products (i.e Mudharabah). The further researches needs to be conducted to identify the root causes for such a phenomenon of Mudharabah paradox and subsequently detailed proposals to 
revive its practice have to be developed.

\section{REFERENCES}

Parasuraman, A. Zeithmal V.A. and Berry, L 1988, SERVQUAL: a multiple-item scale for measuring member perceptions of service quality. Journal of Retailing, Vol. 64, Spring.

Sumiyanto, Ahmad 2008. BMT Menuju Koperasi Modern: Panduan Untuk Pemilik, Pengelola, dan Pemerhati Baitul Maal wat Tamwiil dalam Format Koperasi. Yogyakarta: ISES Publishing.

Andriani. 2005. Baitul Maal Wa tamwiil (konsep dan mekanisme di Indonesia). Empirisma.

BPS Catalog: 1101002.34, "Statistik Daerah IstimewaYogyakarta 2003". Badan Pusat Statistik special region of Yogyakarta Province.

Siamat, Dahlan 1995. Manajemen lembaga keuangan. Jakarta: intermedia

Sunyoto, Danang. 2013. Metode dan Instrumen Penelitian (Untuk Ekonomi dan Bisnis). Yogyakarta: CAPS (Center for Academic Publidhing Service)

Djazuli, 2002. Lembaga-lembaga Perekonomian Umat, Jakarta: PT. Raja Grafindo Persada.

Zubaidah, Siti. 2010. Pengembangan Model Sistem Pengendalian Aliansi "Alkamil" di Malang. Malang: Universitas Muhammadiyah Malang.

Huda, Nurul \& Heykal, Muhammad. 2010. Lembaga keuangan islam: tinjauan teoritis dan praktis. Jakarta: kencana

Ananta, Irwin. 2012. Tinjauan Kritis Praktek Mudharabahh Pada Perbankan Syariah. Paper on national seminar, BSI Univercity. Bandung

Putong, Iskandar. 2003. Pengantar Ekonomi Mikro \& Makro Edisi 2. Bogor: Ghalia Indonesia

Tarmidi, Lepi T. Krisis Moneter Indonesia. Sebab, Dampak, Peran $I M F$, dan Saran. Revision and updating from grand teacher inaugural speech at Economic Faculty Indonesia University under title "Krisis Moneter Tahun 1997/1998 dan Peran IMF"

Wafa, M. Agus Khoirul and Nasrodin. 2008. "Bait Al-Maal Wa At-Tamwiil", Yogyakarta: Universitas Islam Indonesia

Obaidullah, M., Latiff, Hajah Salma Haji Abdul. 2008. Islamic Finance For Micro And Medium Enterprises. Islamic Research \& Training Institute Islamic Development Bank, Centre for Islamic Banking, Finance and Management Universiti Brunei Darussalam

Todaro, Michael P.. 2003. Economic Development $8^{\text {th }}$ Edition. London: Pearson Education Limited.

Qudratullah, Mohammad Farhan. 2009. Analisis Regresi Terapan: Teori, Contoh Kasus dan Aplikasi dengan SPSS. Yogyakarta: CV. Andi Offset

Obaidillah, Mohammed. 2008. Introduction to Islamic Microfinance. India: IBF Net: the Islamic Business And Finance Network

Ridwan, Muhammad. 2004. Manajemen Baitul Maal wa Tamwil. Yogyakarta: UII Press.

Mankiw, N. Gregory. 2007. Macroeconomics, $6^{\text {th }}$ Edition. New York: Worth Publisher.

Pusat Pengkajian dan Pengembangan Ekonomi Islam (P3EI) Universitas 
Islam Indonesia Yogyakarta. 2008. Ekonomi Islam. Jakarta: PT. Raja Grafindo Persada

Ridha Nugraha. Manajemen Pembiayaan: Panduan Untuk Koperasi Syariah. SDM Kementrian Koperasi

Rosly, Saiful Azhar. Critical Issues on Islamic Banking and Financial Markets. Kuala Lumpur-Malaysia: Dinamas Publishing.

Sadono Sukirno. 2006. Mikro Ekonomi Teori Pengantar. Jakarta: PT Raja Grafindo Persada.

Sukirno, Sadono. 2008. Makroekonomi Teori Pengantar Edisi Ketiga. Jakarta: PT. Raja Grafindo Persada.

Azwar, Saifuddin. 2013. Reliabilitas dan Validitas Edisi 4. Yogyakarta: Pustaka Pelajar.

Saiful Azhar Rosly. Critical Issues on Islamic Banking and Financial Markets. Kuala Lumpur-Malaysia: Dinamas Publishing.

Sejarah Bank Indonesia: Perbankan Periode 1997-1999. Unit Khusus Museum Bank Indonesia: Sejarah Bank Indonesia. 